\title{
25. GEOCHEMISTRY OF CARBON: INTERNATIONAL PHASE OF OCEAN DRILLING PROJECT LEG 601
}

\author{
Karl S. Schorno, Phillips Petroleum Company, Bartlesville, Oklahoma
}

\section{INTRODUCTION}

The 11 frozen cores from the Mariana Trough area from Holes 452 through 455, 459B, 460, and 460A are characteristically low in organic carbon (less than $0.2 \%$ ) and contain a predominance of $n$-alkanes within the saturates fraction. There is no odd-predominance of $n$-alkanes as is typical of immature recent sediments. However, recent sediments containing immature organic matter with normal distributions of $n$-alkanes $\overline{(O E P}^{2}$ approximately equal to 1) are characteristic of sediments derived from purely marine sources (Brooks, 1970; Powell and McKirdy, 1973; Tissot et al., 1975). This type of sediment is very rare. However, at least one case where an immature sediment contains an $\overline{O E P}$ of near 1 has been reported in samples similar to those reported herein-that is, the Cariaco Trench (Hunt, 1979).

\section{SAMPLING AND STUDY PROCEDURES}

The method used to isolate the organic matter in these sediments is as follows. Each core section is removed from its core liner. The outer crust of each extracted section is removed to decrease the chance of core liner contamination. The core is then air-dried and crushed to pass a 100-mesh screen. A representative portion of the sieved material is analyzed for organic and carbonate carbon and organic nitrogen. The remaining sieved core is extracted with dichloromethane. The solvent is removed at $40^{\circ} \mathrm{C}$ and the extract weighed. The extract (the bitumen fraction) is then chromatographed over silica gel into three fractions: a saturates fraction with $n$-pentane eluent, an aromatic fraction with dichloromethane, and an asphaltic fraction with methanol-dichloromethane. The saturates fraction is then chromatographed on a $300 \mathrm{ft} . \times 0.01 \mathrm{in}$. WCOT OV 101 glass capillary column. With the exception of the extract from Section 453$18-4$, which was urea-adducted and then chromatographed on a packed $10 \mathrm{ft} . \times 1 / 8 \mathrm{in} . \mathrm{OV} 101$ column, all of the $n$-alkanes chromatographed on the capillary column are resolved. Moreover, base-line resolution of $n-\mathrm{C}_{17}$ from pristane and $n-\mathrm{C}_{18}$ from phytane is also achieved on this column. $n$-alkane distributions and pristane to phytane and pristane to $n-\mathrm{C}_{17}$ and phytane to $n-\mathrm{C}_{18}$ ratios are calculated from these chromatograms. No plasticizers were detected in these chromatograms as

\footnotetext{
1 Initial Reports of the Deep Sea Drilling Project, Volume 60

$2 \overline{O E P}=$ Odd-even predominance.
}

had been previously reported (Erdman and Schorno, 1979).

\section{RESULTS}

All 11 cores from the seven sites studied are similar in organic geochemical properties. With the exception of Core 453-10 (Section 1), each core listed in Table 1 contains less than 0.27 per cent organic carbon (average of $0.11 \%$ ). The bitumen content in each is also lowranging, from 10 to $150 \mathrm{ppm}$, with the exception just noted. In this case (i.e., Section 453-10-1), the soluble organic content equaled $5330 \mathrm{ppm}$. In all but two cores the bitumen fraction consisted of less than 3.3 per cent of the total organic carbon present. The bitumen carbon portion of the total organic carbon of the remaining two core sections (Sections 453-10-1 and 460-4-4) amounted to 50.9 and $8.3 \%$, respectively.

The gas chromatography profiles of each saturate fraction indicate that this fraction is made up primarily of $n$-alkanes and isoprenoids (i.e. norpristane, pristane, and phytane). Very little unresolved hydrocarbons (the so-called humpanes) are observed in these saturate fractions. Nine out of the 11 cores studies contain a relatively normal distribution of odd to even $n$-alkanes in the $n-C_{23}$ to $n-C_{35}$ range as given by $\overline{O E P}$ (Scalan and Smith, 1970) of less than $1.4, \overline{O E P}$ is equal to only 1.5 and 1.6 for the remaining two. There is a predominance of lower molecular weight $n$-alkanes as noted by the ratio

$$
S=\left(n-\mathrm{C}_{21}+n-\mathrm{C}_{22}\right) /\left(n-\mathrm{C}_{28}+n-\mathrm{C}_{29}\right)
$$

being greater than 1 (Table 2 ). The ratio of pristane to phytane in these saturate fractions is consistently less than 1 as also noted in Table 2. Similarly, the ratios of pristane to $n-\mathrm{C}_{17}$ and phytane to $n-\mathrm{C}_{18}$ are consistently less than 1 .

The carbon isotopic composition of the asphaltic fractions listed in Table 3 is relatively constant $\left(\delta^{13} C_{\text {PDB }}\right.$ $=-26.7)$ for all but the asphaltic fraction from Section $460 \mathrm{~A}-1-5$. In this case, the $\delta$ value is -23 . Because the asphaltic fraction predominates in most of the bitumens studies herein, the $\delta$ value of this fraction is indicative of the value of the total bitumen. Supporting this last statement are the findings that the $\delta$ values of the saturate and aromatic fractions of at least two bitumens from Sections $453-10-1$ and $460-4-4$ are only slightly lower than those of the asphaltic fraction.

In general, the saturate and aromatic portions of the bitumen are approximately equal (Table 2). Each is 
Table 1. Geochemical data from IPOD Leg 60: Chronostratigraphy, depth, carbonate and organic carbon, bitumen composition, and $\overline{O E P}$.

\begin{tabular}{|c|c|c|c|c|c|c|c|c|c|}
\hline \multirow[b]{2}{*}{ Core } & \multirow[b]{2}{*}{ Section } & \multirow[b]{2}{*}{ Chronostratigraphy ${ }^{a}$} & \multirow[b]{2}{*}{$\begin{array}{l}\text { Sub-bottom } \\
\text { Deptha } \\
\text { (m) }\end{array}$} & \multicolumn{2}{|c|}{ Carbonate } & \multicolumn{2}{|c|}{ Organic Carbon } & \multirow[b]{2}{*}{$\begin{array}{l}\text { Bitumen/Total } \\
\text { Organic Carbon } \\
\text { (wt. \%) }\end{array}$} & \multirow[b]{2}{*}{$\overline{O E P}$} \\
\hline & & & & $\begin{array}{l}\text { Carbon } \\
\text { (wt. \%) }\end{array}$ & $\begin{array}{c}\text { As } \\
\mathrm{CaCO}_{3} \\
\text { (wt. \%) }\end{array}$ & $\begin{array}{c}\text { Total } \\
\text { (wt. \%) }\end{array}$ & $\begin{array}{l}\text { Bitumen } \\
\text { (ppm) }\end{array}$ & & \\
\hline \multicolumn{10}{|l|}{ Hole 452} \\
\hline 2 & 5 & Upper Pleistocene & 16.0 & 0.15 & 0.018 & 0.14 & 30 & 1.9 & 1.4 \\
\hline \multicolumn{10}{|l|}{ Hole 453} \\
\hline 2 & 3 & Upper Pleistocene & 13.0 & 0.14 & 0.017 & 0.12 & 50 & 3.3 & 1.1 \\
\hline 10 & 1 & Lower Pleistocene & 86.0 & 0.28 & 0.034 & 0.84 & 5330 & 50.7 & 1.1 \\
\hline 18 & 4 & Upper Pliocene & 166.5 & 0.41 & 0.049 & 0.09 & 30 & 2.5 & 1.6 \\
\hline 29 & 2 & Lower Pliocene & 268.0 & 0.12 & 0.014 & 0.12 & 20 & 1.2 & 1.2 \\
\hline \multicolumn{10}{|l|}{$\underset{4}{\text { Hole } 454 \mathrm{~A}}$} \\
\hline \multirow{2}{*}{\multicolumn{10}{|c|}{ Hole 455}} \\
\hline & 5 & Upper Pleistocene & 16.0 & 0.31 & 0.037 & 0.05 & 10 & 1.5 & 1.2 \\
\hline \multicolumn{10}{|l|}{ Hole 459B } \\
\hline 6 & 2 & Lower Pleistocene & 47.0 & 0.18 & 0.022 & 0.06 & 10 & 0.8 & 1.5 \\
\hline 30 & 2 & Lower Miocene & 275.0 & 0.33 & 0.040 & 0.06 & 10 & 1.0 & 1.3 \\
\hline \multicolumn{10}{|l|}{$\begin{array}{l}\text { Hole } 460 \\
4\end{array}$} \\
\hline 4 & 4 & Pleistocene & 33.0 & 0.15 & 0.018 & 0.14 & 150 & 8.3 & 1.2 \\
\hline \multicolumn{10}{|l|}{ Hole 460A } \\
\hline & 5 & Pleistocene & 6.0 & 0.18 & 0.022 & 0.27 & 40 & 1.2 & 1.4 \\
\hline
\end{tabular}

a Both chronostratigraphy and sub-bottom depth obtained from the Leg 60 Initial Core Descriptions.

small as compared with the asphaltic portion; however, the shallowest section in each site contains the highest amount of asphaltics as is expected because these units are considered the most immature. The amount of asphaltic as compared with saturate and aromatic fractions should decrease with depth or maturity and generally does with the exception of Section 453-10-1. For this case, the amount of asphaltic as compared with the sum of saturate plus aromatic fractions is unusually low. Because the organic content and the bitumen portion of the organic content of this section are much higher than those of adjacent strata, the bitumen within this particular core may not be indigenous to the unit.

The ammonium and organic nitrogen content in these cores is relatively low, averaging $46 \mathrm{ppm}$ (with a range from 31 to $92 \mathrm{ppm}$ ) and $160 \mathrm{ppm}$ (with a range from 2 to $434 \mathrm{ppm}$ ), respectively. The atomic ratios of organic carbon to organic nitrogen are also relatively constant (averaging 18, with a range from 4 to $81 \mathrm{ppm}$ ). Ex-

Table 2. Organic geochemical data from IPOD Leg 60: Composition of $n$-alkanes and the isoprenoids pristane and phytane.

\begin{tabular}{|c|c|c|c|c|c|}
\hline Core & Section & $\begin{array}{c}\text { Marine/Terrestrial } \\
n \text {-Alkanes }(S)^{\mathrm{a}}\end{array}$ & Pristane/Phytane & Pristane $/ n-C_{17}$ & Phytane $/ n-\mathrm{C}_{18}$ \\
\hline \multicolumn{6}{|l|}{$\begin{array}{c}\text { Hole } 452 \\
2\end{array}$} \\
\hline \\
\hline 2 & 3 & 1.79 & 0.89 & 0.7 & 0.8 \\
\hline 10 & 1 & 1.35 & 0.81 & 0.7 & 0.8 \\
\hline $\begin{array}{l}18 \\
29\end{array}$ & 4 & 1.53 & ${ }_{0.84}^{\mathrm{a}}$ & $a_{3}$ & ${ }_{0}^{\mathrm{a}}$ \\
\hline \multicolumn{6}{|l|}{ Hole 454A } \\
\hline 4 & 4 & 1.10 & 0.86 & 0.4 & 0.4 \\
\hline \multicolumn{6}{|l|}{ Hole 455} \\
\hline \multicolumn{6}{|l|}{ Hole 459B } \\
\hline & 2 & 3.48 & 0.19 & 0.4 & 2.6 \\
\hline & 2 & 3.53 & 0.66 & 0.4 & 0.3 \\
\hline \multicolumn{6}{|l|}{ Hole 460} \\
\hline Hole $460 \mathrm{~A}$ & 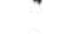 & 3.11 & 1.08 & 0.2 & 0.1 \\
\hline 1 & 5 & 1.28 & 0.8 & 1.8 & 1.9 \\
\hline Average & & $\begin{array}{l}2.00 \\
0.95\end{array}$ & $\begin{array}{l}0.8 \\
0.2\end{array}$ & $\begin{array}{l}0.5 \\
0.5\end{array}$ & 0.8 \\
\hline
\end{tabular}

a Marine/terrestrial $n$-alkanes is given by $S=\left(n-\mathrm{C}_{21}+n-\mathrm{C}_{22}\right) /\left(n-\mathrm{C}_{28}+n-\mathrm{C}_{29}\right)$ (Philippi, 1974). cluding the carbonaceous Section 453-10-1, the range becomes more restricted ( 4 to $25 \mathrm{ppm}$ ). If the organic content in this particular core is similar to that in the other three cores from this site-that is, 0.11 per cent instead of 0.84 -and the excess organic matter is hydrocarbon in nature (possibly a hydrocarbon contaminate), then the ratio of organic carbon to organic nitrogen for this core becomes 10 , as compared with 8,13 , and 11 for the cores above and the two below this section.

\section{DISCUSSION AND CONCLUSIONS}

Some variations in the geochemical properties of these sediments are observed as shown in Tables 1, 2, and 3. With the exception of Section 453-10-1, the variations are so small that one cannot distinguish different organic facies either between sites or within the same sites.

Because these sediments are relatively young in geologic age and appear to have undergone only a mild thermal history, the organic matter in these sediments should be in an early stage of maturation, that is, the diagenetic stage (Tissot and Welte, 1978). The lack of bitumen, the low ratio of bitumen carbon to total organic carbon, and the relatively small proportion of saturated hydrocarbons to total bitumen within these sediments also indicate an early stage of organic genesis.

Historically, if $\overline{O E P}$ is greater than 1.3 , the sedimentary organic matter is considered in the diagenetic stage of evolution. However, as noted by Hunt (1979), in rare cases (such as in one sediment from the Cariaco Trench) immature pelagic sediments that have either little or no terrestrial input contain $n$-alkane distributions with $\overline{O E P}$ values of less than 1.3 . Hunt also reported $\overline{O E P}$ values of approximately $1.2,1.1$, and 1.1 , for marine sponges, corals, and plankton, respectively, indicating that at least for these organisms an odd-carbon preference is not normally found and that most likely such preference is not normal for purely marine sedimentary organic matter. Consequently, the $\overline{O E P}$ values obtained 
Table 3. Geochemical data from IPOD Leg 60: Nitrogen content, bitumen sub-fraction content, and isotopic composition of asphaltic fraction.

\begin{tabular}{|c|c|c|c|c|c|c|c|c|}
\hline \multirow[b]{2}{*}{ Core } & \multirow[b]{2}{*}{ Section } & \multicolumn{3}{|c|}{ Kjeldahl Nitrogen (ppm) } & \multicolumn{4}{|c|}{ Bitumen Sub-Fraction Composition ${ }^{\mathrm{a}}$} \\
\hline & & $\begin{array}{l}\text { Ammonium } \\
\text { Nitrogen } \\
\text { (half) }\end{array}$ & $\begin{array}{l}\text { Organic N } \\
\text { (full-half) }\end{array}$ & $\begin{array}{l}\text { Atomic Ratio } \\
\text { Organic C } \\
\text { Organic N }\end{array}$ & $\begin{array}{l}\text { Saturated } \\
\text { (wt. } \% \text { ) }\end{array}$ & $\begin{array}{l}\text { Aromatic } \\
\text { (wt. } \% \text { ) }\end{array}$ & $\begin{array}{l}\text { Asphaltic } \\
\text { (wt. } \% \text { ) }\end{array}$ & $\begin{array}{c}\text { Asphaltic } \\
\left({ }^{1}{ }^{13} \text { CPDB }\right)\end{array}$ \\
\hline $\begin{array}{c}\text { Hole } 452 \\
2\end{array}$ & 5 & 57 & 434 & 4 & 25 & 18 & 57 & -26.2 \\
\hline Hole 453 & & & & & & & & \\
\hline 1 & 3 & 34 & 199 & 8 & 22 & 22 & 56 & -25.6 \\
\hline 10 & 1 & 48 & 131 & 81 & $40(-28.6)$ & $39(-28.3)$ & 21 & -27.5 \\
\hline 18 & 4 & 61 & 85 & 13 & 33 & 28 & 39 & -27.5 \\
\hline 29 & 2 & 41 & 135 & 11 & 31 & 30 & 39 & -27.2 \\
\hline $\begin{array}{c}\text { Hole } 454 \mathrm{~A} \\
\qquad 4\end{array}$ & 4 & 34 & 51 & 13 & 27 & 23 & 50 & -25.5 \\
\hline Hole 455 & & & & & & & & \\
\hline 2 & 5 & 38 & 22 & 25 & 18 & 19 & 64 & b \\
\hline Hole 459B & & & & & & & & \\
\hline 6 & 2 & 36 & 140 & 5 & b & b & b & \\
\hline 30 & 2 & 38 & 42 & 17 & 31 & 17 & 52 & b \\
\hline Hole 460 & & & & & & & & \\
\hline 4 & 4 & 31 & 140 & 13 & $28(-27.7)$ & $28(-27.5)$ & 44 & -27.1 \\
\hline Hole $460 \mathrm{~A}$ & 5 & 92 & 377 & 9 & 14 & 14 & 72 & b \\
\hline
\end{tabular}

a Where measurable, the carbon isotopic composition of the saturate and aromatic fractions are given in parentheses.

b Insufficient sample for this analysis.

from purely marine sediments should lie close to 1 at the surface of the sediments and also at depth. Thus, based on $\overline{O E P}$ values and the state of diagenesis of these sediments, I conclude that these sediments are autochthonous and examples of truly isolated marine sediments. Additional support for this conclusion is the occurrence of phytane in relatively large abundance along with marine $n$-alkanes and the predominance of phytane over pristane in marine environments.

As already noted, the organic matter in these sediments is derived primarily from marine organisms. This conclusion is based on the ratio of marine to terrigenous $n$-alkanes ( $S$ greater than 1.0), the occurrence of marinederived $n$-alkanes as noted by these immature sediments having an $\overline{O E P}$ value of less than 1.5 , and to a lesser extent a ratio of pristane to phytane of less than 1.0. In the latter case, the pristane to phytane ratio indicates a reducing environment. This suggests (but does not necessarily prove) that the organic matter in these sediments is purely marine in origin. The cut-off values for the two parameters $(\overline{O E P}$ less than 1.5 and $S$ greater than 1.0 for a predominance of marine-derived sedimentary organic matter) are highly subjective. It is therefore difficult to make even semi-quantitative estimates of the amount of marine-derived organic matter within these sediments based on these parameters. For example, had the organic input into the grabens at Holes 453 and $454 \mathrm{~A}$ been purely marine in origin, then both $\overline{O E P}$ and $S$ for these sediments should be more characteristic of a marine source than they are. They would have, for example, on $\overline{O E P}$ less than 1.2 and $S$ greater than 2 . Without a major marine component, their $\overline{O E P}$ and $S$ values should be similar to other sediments from sites more accessible to terrigenous input. In comparing sediments from the Mariana Trough (Sites 453 and 454) with sediments cored deep in the Mariana Basin on the Pacific plate (Site 452 ), from the apron of the Mariana arc (Site 455), from the outer edge of the fore-arc sediment prism (Site 459), and from deep in the Mariana Trench (Holes 460 and
$460 \mathrm{~A}$ ), one finds variations in $\overline{O E P}$ and $S$ that are not entirely consistent with a higher marine proportion of the total organic matter. That is, in some cases $\overline{O E P}$ is low (less than 1.5) and $S$ high (greater than 1.5); in other cases $\overline{O E P}$ is high and $S$ low. For the five Mariana Trough samples, the average $\overline{O E P}=1.2$, which is less than any one value of the remaining six samples from the apron, the fore-arc sediment prism, and the trench. One may speculate that the lower values for $\overline{O E P}$ indicate a higher proportion of marine organic matter in these sediments. However, the trough cores contain less abundant "marine"'-derived $n$-alkanes than for example the cores from the fore-arc sediment prism (Site 459) and the one core (Core 460-4, Section 4) from deep in the Mariana Trench (1.4 versus an average of 3.4 for the three cores just mentioned). In this case, Section 460-4-4 from deep in the Mariana Trench appears to contain a higher marine-organic contribution than the trough cores or other cores in the study area.

Three assumptions are normally made in interpreting $\overline{O E P}$ and $S$ values with respect to the contributions of marine organic matter in sediments. These are not always foolproof. First, marine-derived $n$-alkanes in the $n-\mathrm{C}_{23}$ to $n-\mathrm{C}_{35}$ range contain neither an odd nor an even predominance. Secondly, the odd-predominance of $n$-alkanes, which is normally encountered in immature sediments between $n-\mathrm{C}_{23}$ and $n-\mathrm{C}_{35}$ is determined solely by terrigenous-derived $n$-alkanes. If so, a proportionately larger amount of marine-derived $n$-alkanes is needed to swamp out the odd-predominance of these terrigenous $n$-alkanes. In essence, a 5-to 10 -fold increase in marine over terrigenous organic matter is needed to provide sufficient $n$-alkanes in this range to reduce the normally high $\overrightarrow{O E P}$ value (2.5) to less than 1.5 . Thirdly, all marine organisms generate approximately the same amounts of $\mathrm{C}_{21}$ and $\mathrm{C}_{22} n$-alkanes, and the amounts of these $n$-alkanes can be used to indicate the total amount of marine organic matter present. Similarly, the sum of $n-\mathrm{C}_{28}$ and $n-\mathrm{C}_{29}$ is indicative of the amount of ter- 
rigenous organic matter present, and thus the ratio $S$ is indicative of the contribution of marine-terrigenous organic matter in the sediments. Whether these assumptions are correct is in question at this time.

In conclusion, I believe that the suite of cores studies herein is a good example of cores containing primarily marine-derived organic matter. Additional research is needed, however, to determine the exact contribution of marine organic matter in these sediments, and whether one can distinguish the specific source organisms from which this organic matter is derived. This information will be helpful in future studies to derive a numerical value for the amount of marine contribution to the sedimentary organic matter in these deep-marine basins.

\section{REFERENCES}

Brooks, J. D., 1970. The use of coals as indicators of occurrence of oil and gas. APEA Journal (Australia), 10 (2):35-50.
Erdman, J. G., and Schorno, K. S., 1979. Geochemistry of carbon: Deep Sea Drilling Project Legs $47 \mathrm{~A}$ and B. In Ryan, W. B. F., Sibuet, J.-C., et al, Init. Repts. DSDP, 47, Pt. 2: Washington (U.S. Govt. Printing Office), 553-559.

Hunt, J. M., 1979. The source rock. In Petroleum Geochemistry And Geology: San Francisco (W. H. Freeman Company), 302-303.

Philippi, G. T., 1974. The influence of marine and terrestrial source material on the composition of petroleum. Geochim. Cosmochim. Acta., 38:947-966.

Powell, T. G., and McKirdy, D. M., 1973. The effect of source material, rock type and diagenesis on $n$-alkane content of sediments. Geochim. Cosmochim. Acta, 37:623-633.

Scalan, R. S., and Smith, J. E., 1970. An improved measure of the odd-even predominance in the normal alkanes of sediment extracts and petroleum. Geochim. Cosmochim. Acta, 34:611-630.

Tissot, B. P., Pelet, R., Roucaché, J., et al., 1975. Utilisation des Alcanes Comme Fossiles Géochimiques Indicateurs des Environments Géologiques. Institut Français du Pétrole, Ref. 23, 440: Paris (Institut Français du Pétrole), 26.

Tissot, B. P., and Welte, D. H., 1978. Diagenesis, catagenesis and metagenesis of organic matter. Petroleum Formation and Occurrence: $A$ New Approach to Oil and Gas Exploration: New York (Springer), 70-73. 